\title{
Islamic Dealings with Non-Muslims in Their Religious Occasions
}

\author{
Mohammed Sabbar Taha ${ }^{1}$, Abdull Rahman Mahmood ${ }^{1}$, Jaffary Awang ${ }^{1}$, Ahamd Munawer Imail ${ }^{1} \&$ Mohammed \\ Abdulhameed Sleibi ${ }^{1}$ \\ ${ }^{1}$ Jabatan Usuluddin dan Falsafah, Fakulti Pengajian lslam, Universiti Kebangsaan Malaysia, Malaysia \\ Correspondence: Jabatan Usuluddin dan Falsafah, Fakulti Pengajian 1slam, Universiti Kebangsaan Malaysia, \\ 43600 UKM Bangi, Selangor, Malaysia. Tel: 6011-2828-6055. E-mail: mo177m@yahoo.com
}

Received: May 7, 2016

doi:10.5539/mas.v10n10p55
Accepted: May 27, 2016

Online Published: June 29, 2016

URL: http://dx.doi.org/10.5539/mas.v10n10p55

\begin{abstract}
In this study, one of the main comprehending features of Islamic legislation is that all religions; whether they are celestial or not from the Islamic countries, it is stated in the legislation regarding dealing controls with non-Muslims such as how to deal with them in their religious and non-religious occasions. Recently, there some overtaking from some Muslims during the participation of non-Muslims in their occasions, especially in (holidays), refers to different reasons. The objectives and methods of this study mentioned that the jurists' sayings include religious rituals as well as exclude them. This issue requires the topic from the belief side, using induction approach texts and analyzing the sayings. In conclusion, this study leads to the prohibition of participating in their religious occasions, except that serves religion and Muslims. In addition to what is necessary it is permissible to participate in occasions which don't have religious rituals, and clarify negative effects in participation and ways of treatments.
\end{abstract}

Keywords: Islamic dealings, non-Muslims, religious occasions

\section{Introduction}

One of the blessings of god on fairies and humans is that Allah makes Islam as a religion of mercy for them, that all the previous books that were sent by God, invalidate all beliefs' positions, and practices which in conflict with the Islamic legislations, among the most prominent qualities is surviving and lake of deviation is to preserving the consistencies, so any disruption leads to unsteadiness as other legislation deviated from what was planned for it. The most important consistency is the belief side and it is the basis of religion. Allah says:

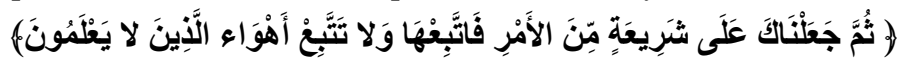

(what means: Then we have made you follow a course in the affair, therefore follow it, and do not follow the low desires of those who do not know, Algathiah, 18), and what is happening today in irregularities from Dhimmis shows the religious rituals in churches and temples in Islamic countries and the permission for Muslims to participate in them, which leads to imitation, and some believe in the truth of those practices and rituals, in spite of the prohibition of this in the Qur'an, sunnah and consensus, and the scholars have presented the details in relation to the ruling of participation and the complacency in it, showing the negative effects, which affect the beliefs and social aspect in Islamic countries.

\section{The Status of Non-Muslims in Islamic Legislation}

Tolerance is one of the most promoted characteristics with respect to Islamic legislation, as Prophet Mohammed peace be upon him said:

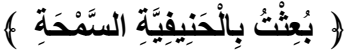

(What means: I was sent with tolerance of hanafeyyah. Allah almighty prevents arguing people of the book except in the manner, which does not lead to hatred and affect their feelings). Allah says:

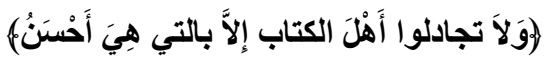

(And do not dispute with the followers of the books, Al Ankaboot), an example of tolerance given to non-Muslims is permission to marry from the people of the books, Allah almighty say:

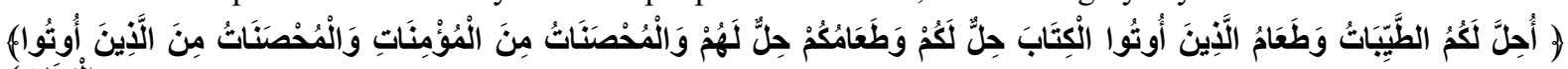

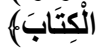


(what means: This day (all) the good things are allowed to you; and the food of those who have been given the book is lawful for you and your food is lawful for them; and the chaste from among the believing women and the chaste from among those who have been given the book before you, Al-Maeda, 5), and cousins or sons from non-Muslims, and relatives among them, which leads to participation in occasions in general.

The Islamic legislation says we must respect religious freedom and it prevents compulsion in religion and gives non-Muslims minorities the right to practice their own religious rituals, through the controlled condition with dhimmis, that cannot be in harmony with other religions, such as the Romanians legislated death for the violators in re logons from killing, persecution, displacement and destroy temples (sayyed Qutb, in the Shadows of Qur'An, 1/291), Islam orders us to protect dhimmis people from external aggression., Thus, the imam must protect dhimmis from Muslims and non-Muslims, and rescue those captured by Muslims, and return what was taken from them (Ibn, Q., Al-Maqdisi, Alkhaffy in Imam Ahmed Fiqih, 4/181).

In this context, a legislation that equates Muslims and non-Muslims which is not found in other religions, Mawerdy said:

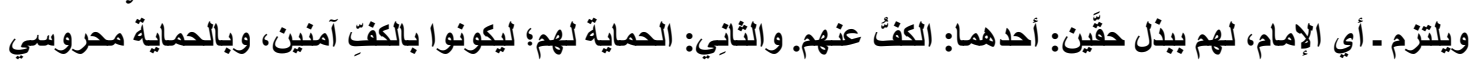

The imam committed is given two rights: one of them to prevent heart and secondly: the protection for them to be safe through preventing heart and to be safe (Almawerdy, AlAhkam, \& Alsultaniah, 1/223).

Also, the Islamic legislation orders the protection of them from any attack in Islamic country, the prophet Mohammed peace be upon him once said:

\section{من قتل معاهذًا لم يرح رائحة الجنة، وإنّ ريحها توجد من مسيرة أربعين عامًا}

(What means: Who kills a person in a treaty can't see the paradise smell and it's blowing can be found from a forty years distanc). Ibn Hajr said:

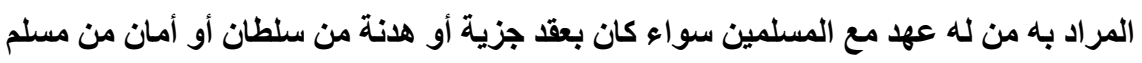

It means one who has a treaty with Muslims whether in ransom contract or a treaty from sultan or safe from Muslim (Al-Asqlani, Al-bari, \& Al-bukhari, 12/259).

The best example shows the tolerance and justice in Islamic legislation with non-Muslims, to give them freedom in practicing their rituals, as the evidence of prophet Mohammed peace be upon him to open Khyber by force and to protect temples without destroying them and the companions who were blessed by Allah invaded many countries and didn't destroy any church or temple (Ibn, N., the Minutes of Treasure Explanation, 5/122).

In genayat's omar bin abdul Aziz said: he worked for some princes about a Muslims killed dhimmi; he ordered him to leave him to sponsor, if he wanted to kill him, if he wanted to forgive him. So his sponsor killed him (Abdulrazzaq, Abdulrazzaq Categorization, 10/101). Also through the jurists' differences in this issue in terms of judgment but the witness has insured the Muslims' rights in Islamic society through insuring the social rights for them when they get old and unable to acquire money, which is known as social welfare. It was narrated that Omar bin alkhattab (may Allah bless him), a Jewish old man went asking people, so Omar asked and knew that he was needy because he was too old and unable to work. So Omar took him to his house and gave him what he could find then he sent him to the financial welfare house, and he ordered him and his similarities to give what was necessary from Muslims welfare house and he said:

\section{ما أنصفناه إذ أخذنا منه الجزية شاباً، ثم نخذله عند الهرم.}

We were fair when we took ransom from him when he was young and don't humiliate him when he is gets old (Abu, Y., Al Kharaj for Abu, Y., 1/39).

\subsection{Participation in Occasions}

Eids are the most important rituals in Islamic religion; Allah has made two eids for Muslims: the sacrifice eid (Al-adha) which comes at the end of the pilgrimage to the holly mosque in mecca. And animal sacrifice is the greatest during eid $\mathrm{Al}$ adha. Whereas, eid $\mathrm{Al}$ fitir comes after the completion of fasting in Ramadan and it is of the greatest offer in this month of charity. The two eids are to show the greatest thanks to Allah through obedience and the happiness to obtain later, and Muslims become joyful, which shows the greatest power of Allah, in addition of visiting relatives and friends ( Al-khazen, explanation, 1/157). Whereas the most Christian holidays for celestial legislation, it comes up to ten festivals, in addition to special holidays for each doctrine, and the other doctrines deny it, the most prominent agreed is Easter holiday, which is celebrated on the 25th of December.

Religions have different holidays, the most famous is Hinduism and Buddhism, each one has rituals in their 
holidays, Indian festival is considered as a feast and the Indians believe that they get rid of evil Gods from good Gods, that they call it colors festival.

The Chinese new year festival starts from the celebration of the beginning of the first lunar month in Chinese new year and it ends on the fifteenth day of that month, and the first day is called lantern festival and the celebration hilds in the main religious Chinese festivals at the beginning of that year, and families pray in groups and thank their Gods for the last year. Also, they color the windows and doors red. Moreover, they exchange gifts with red envelopes (the Global Arabic Encyclopedia, 1-1-9).

Based on the above demonstration we should clarify the evidences regarding the rulings of participations in the festivals as follows:

(1) The book (Quran): Allah almighty said:

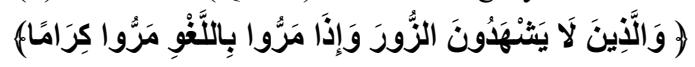

(what means: And they who do not bear witness to what is false, and when they pass by what is vain ,they pass by nobly, al furqan 72), az-zour is: participation of non-Muslims in their holidays (Qurdoban Explanation, 13/79), and it is a prohibition in Islamic legislation.

(2) Sunnah: Thabit ibn Aldahak said:

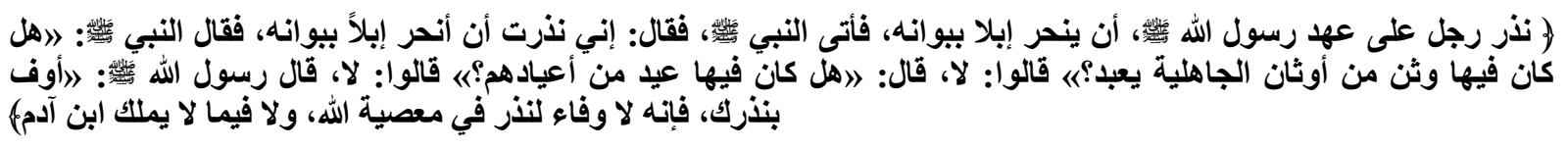

(what means: There is a man who vowed at the time of prophet Mohammed peace be upon him, to sacrifice a camel, then prophet Mohammed peace be upon him came and the man said: I vowed to sacrifice a camel, the prophet Mohammed said: Was it an idol of ignorance which worships? They said: No. the prophet said: Is it one of their feasts, they said: No, the prophet said: Implement your vow, so there is no fulfilling a vow in disobedience to Allah, nor in the son of Adam (Abu, D., \& Sunan, A. D., 3/238), the evidence of hadith means it is a prohibition for muslims to participate with the unbelievers at their places of worship.

(1) The consensus: Scholars have prohibited participation with them, but sometimes, it's permissible to show participation because of their belief characteristics. So, it is not permissible for Muslims to help them or attend a religious festival (Al-Qayim, Ahkam, \& Al-dhimmi, 3/1245), but in the modern era, some scholars such as sheik Youssef Al-Qardawi has given legal opinion to congratulate them and swap gifts (not forbidden things) because of the change of time. According to him, participation in their celebrations, Al-Qardawi said it is not permissible, because each religion has its own privacy. In addition to this, we will show the details in the next topic (Al-Qardawi, Minority's Fiqh Life of Muslims inside Other Societies).

(2) Mind: The holidays are one of the worship rituals in all celestial religions which are characterized by that. So, the Islamic legislation includes this ritual and Allah almighty has enriched us from other religious rituals, Allah said:

\section{(لكل جعلنا منكم شرعة ومنهاجاي)}

(What means: For every one of you did we appoint a law and a way, Al-Maeda 48), there is no justification to participate in their holidays.

\subsection{The Reasons Leading for Participation are As Follows}

(1) Mixing of Muslims with non-Muslims minorities in Muslim countries such as Malaysia, in the same area of different ethnics and religions and as a result of this presence, social relations and dealings will emerge such as visiting and congratulations in religious occasions especially, participation on holidays, also the partnership in public and private sectors (Malaysian Experiment, 1/53). As the presence of Islamic minorities in the non-Islamic countries because of the political, social and economic problem, or to study, or some Muslims married other ethnic folks leading to social relationships and participations.

(2) The role of media which has a great impact on the modern ages in all societies, the non-Muslims countries publish their celebrations and rituals, so Muslims are affective in their participation (Encyclopedia of Intellectual and Cultural Invasion and Its Impact on Muslims, 3/143).

(3) The ignorance of belief provisions brought by Islamic religion especially in the non-Muslims occasions mostly in holidays. While Islamic legislation shows related controls (Ministry of Awqaf Egypt, 7/393).

(4) The lack of religious faith: As a result of not implying religions rulings whereas the causes of this weakness in some people is following wrong desires of what is happening in these situations such as low morality and 
taking alcohol (Encyclopedia of Fiqhiyyah Wait, 7/12).

(5) Some of the associates of Islam set out the legality participation, which shows that Islam is open to tolerance, which leads to a permission of participation in non-Muslims' rituals, and do not accuse Islam in reactionary and obscurantism (Abayan Journal: http://mesr.egyptianforum.net/t12693).

(6) The policy of Muslims rulers: One of the duties of Muslims rulers leading to reform the Muslims' affairs in any case and money, which is suitable to the purpose of legitimacy of Islam, and participation to remove affliction, which leads to harming the religion and Muslims, that causes ethnic war, which causes the intervention of enemy states through providing them with different ways which is detrimental for the countries, based on the fundamentalist rule and it is: "to have less of the two detrimental or to prevent the strongest". (Alanzy, Facilitate the science of jurisprudence (fiqh), as a result Muslims will be affected).

(7) Constitutions and laws: In the majority of Islamic countries the constitution and laws allow to the non-Muslims minorities and give them absolute freedom in practicing and showing their holidays and rituals without any conditions, for example: The Iraqi rules say: the constitution is guaranteed to protect the Islamic identity for the majority of Iraqi people also all the religious rights for all people in practicing religions like Christians and Yazidis and sabia's (minority rights sections, Iraqi tribes are the sources of national prosperity $1 \backslash 3)$.

2.3 The Provisions of Participation Ruling in Occasions, the Scholars Have Different Opinions in the Legality of Participation of Muslims with Non-Muslims' Occasions

\subsubsection{Religious Occasions}

Alhanafeia said that if Muslim intended veneration in participation in non-Muslims holidays, he is an infidel (Ibn Najim, Calm Sea Accuracies Treasure Explanation, 5\133), and the Malikis said: the Muslim will be infidel if he intends veneration in participation (Ibn, R., Demonstration and Collection, 31276), Alshafe'I said: A Muslim should be given penalty. Also a Muslim who participates with non-muslims in their holidays should be given a penalty, al sharbini, the enrichment of needy for the knowledge of the meaning of curriculum 61526] if non-Muslim gives a Muslim for their holidays, it is permissible to accept it expect meat (flesh). As a woman asked Aisha may Allah bless her, said: The Magians people bring us gifts during feast, but Aisha said: do not eat from their trees (green vegetables) (Abu, S., Classification, 5\126). In the modern era alshaikh yousef alqaradawi said: it's permissible to exchange congratulations and gifts between Muslims and non-Muslims in religious occasions during the festivals, so the reason for permission to acquire mutual respect and good relations between people in modern era. The great evidence that the prophet Mohammad peace be upon him accepted gifts from non-Muslims, as al moqawqas cyres. The great copts in Egypt (Al-Qardawi, Minorities Jurisprudence (fiqh), Muslims' Life in the Middle of Other Societies, 1\145)。 Whereas the approval for ruling of non-Muslims with respect to holidays and occasions as delaying or preceding the first day of fasting (Ramadan) or ashura'a or the month of rajab. So, it's not permissible to determine the first of these Muslims' occasions because Allah Almighty has made them absolutely conditioned with crescents, Allah Almighty said:

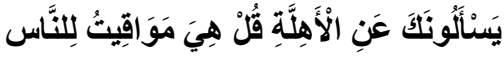

(They ask you concerning the new moon. Say: They are times appointed for the benefit of men, al baqara 189). As a ruling of participation of non- Muslims in their holidays is prohibition of participation is not implying any taboo such as: drinking alcohol, so its allowed to participate with them to acquire religions interest to remove hatred and glamour, as it can affect Islamic nation, as in Egypt, Iraq and Syria and other countries, or in this participation to call for Islamic.

(1) Non- religious occasions.

Which do not have Islamic features? So it is permissible to accept their invitation, and congratulate them on it: wife or son or absent person coming from travel or safety from hatred, or visit a patient, Albukhari narrated from Anas, and said:

كان غلام يهودي يخدم النبي : (what means: A young Jew was serving the prophet Mohammed peace be upon him and the Jew became ill, so the prophet visited him, sat near his head and said adopt Islam and he looked at his father, and said: Obey the prophet abu Al-Qasim, he adopting Islam and the prophet went out praising to Allah that saved him from fire or hell (Al-Bukhari, \& Sahih, A. B., 2/94)). Also a response verdict upon the call to churches and temples for non-religions occasions, the scholar differed in its ruling. So, the hanafi's belief (Al-ballkhi, Indian Fatwa: 1/347), Malki (Al-Raeni, Talent of Galilee in a Brief Explanation of Khalil, 4/3), shafe'i, (Al-Ansari, \& Al-Gharar, G., Delight in Explaining the Rosary, 210/4). And 
novel Ahmed to respond and the other novel of prohibition (Al-bahwati, Kashal, \& Al-Qina'a, 1/169). So, they have got the evidence of sham's tramp that the Christians made food for the khalifa Omar be pleased with him when he come to sham, and asked: where is he? They said in the church. So he refused to go and ordered Ali may Allah be pleased with him to enter the church and had lunch with Muslims. Then Ali looked at the pictures and said what if the khalifa Omar entered and had lunch (Ibn, Q., \& Al-Mughni, 7/283) the most correct in this issue, that it's permissible to participate in their public occasions except those which include religions rituals, also we can visit sick people and give relief to needy people.

\subsection{The Most Important Method and Means for Treating the Negative Effects in Participation of Non-Muslims} Celebration So It

\subsubsection{The Consequences}

(1) Those who agreed non-Muslims in all holidays and practices with their religious rituals occasions such as prayer, hymns and other rituals, so negative effects lead to abandoning his religion and adopting their religion.

(2) They lead also to the acquisition of morals and custom which differ from our societies, leading to differences in Islamic societies.

(3) There will be notification of humiliation to Muslim.

(4) The participation of non-Muslims holiday leading to indifferences or caring of Islamic holidays (eids), because self has taken great role of playing and amusement in their holidays.

\subsubsection{Way of Treatment}

Negative effects should be treated, the most important ways are:

(1) The role of scholars, students and preachers to remove ignorance to those in charge by informing, clarifying and being proud of our religion, because it enriches as from other religions.

(2) The correct approach through using media to clarify the duties and rights for non-Muslims, which brought to them by the true Islamic legislation without excess not negligence.

\section{Discussion}

The important and the need of this topic to Muslims, mostly in the modern era, because they associate others. The Islamic religion has ensured for people of celestial and non-celestial the right to practice their religious rituals and to have citizenship as they remain committed to the conditions of dhimmis people. The jurist's agreement prohibited the participation of Muslims in their holidays and it's permissible in other occasions which do not have religious rituals. Negative consequences of participating in their holidays will emerge which have great effects upon Muslims belief which affect the Muslim society. The most important methods and means for treating the negative effects in participation of non-Muslims celebration so it.

\section{Acknowledgments}

We would like to thank Universiti Kebangsaan Malaysia (UKM) for their support to complete this study.

\section{References}

Abdul, R., Abu, B., Abdul, R., \& Bin Hammam, S. (1982). Controllers Abdul Razzaq (2nd Floor), Achieve: Habib Rahman Al-Aadhami, Beirut: Islamic office.

Abu, D., Suleiman, bin Asha'ath, bin Ishaq, bin Bashir, bin Shadad ... Azdi, S. (2002). Sunan Abi Dawood, the investigator: Muhammad Muhyiddin Abdul Hamid Beirut: The Modern Library.

Abu, S., Abu, B. A., bin Mohammed, bin Ibrahim, bin Othman, bin Khawasti, \& Al-Absi (1989). Seeded in conversations and effects, Investigator: Kamal Yusuf Pisces, Riyadh: Al-Rushed Library.

Abu, Y., Jacob, bin Ibrahim, bin Habib, bin Saad, bin habtah, \& Al-Ansari, D. T. (2002). Abscess, Cairo: Al-Azhar Heritage Library.

Al-Ansari, Zakaria, bins Mohammed, bin Ahmed, bin Zakaria, Al-Ansari ... Abu, Y. A. (2010). Al-Gharar gorgeous delight in explaining the Rosary. The Printing Press Almimnah.

Al-Anzi, Abdullah, bin Yousef, bin Isa, bin Yacoub, Al-Yacoub, \& Al-Judaie (1997). To facilitate the science of jurisprudence, Beirut: Al Rayyan Foundation for Printing, publishing and distribution.

Al-Asqalani, Ahmed, bin Ali, bin Hajjr, Abu, F., \& El-Shafei (1960). Fath albari in sahih al-bukhari, Beirut: Dar knowledge.

Aljmaeili, Ibn, Q., Al-Maqdisi, Abu, M., Mwafaquddin, A., bin Ahmed, \& bin Mohammed (1994). Sufficient in 
the jurisprudence of Imam Ahmad, Beirut: Dar scientific books.

Al-Mawardi, Abu, A. H., bin Ali, bin Mohammed ... Al-Baghdadi (1989). Verdicts Bowl, Cairo: Dar Al-Hadith.

Al-Qaradawi, \& Joseph (2001). Jurisprudence of Muslim minorities amid other communities, Cairo: Dar El Shorouk.

Al-Qaradawi, \& Joseph (2001). Jurisprudence of Muslim Minorities-Muslim life amid other communities, Cairo: Dar El Shorouk.

Alraeina, Shamsuddin, Abu, A., Muhammad, Ibn, M., Ibn, A., \& Al-Rahman (1992 AD). The talents of Galilee in a brief explanation Khalil (3rd Floor), Beirut: Dar Thought.

Balkhi, Nizamud-Din, \& Balkhi (1893). Indian Fatawa (2nd Floor), Beirut: Dar Al-Fikr.

Global Arabic Encyclopedia (1999). Adopted in some of its parts on the international version of the World Encyclopedia, 16, 170.

Goleman, D. (2009). What makes a leader? In D. Demers (Ed.), AHSC 230: Interpersonal communication and relationships, 47-56. Montreal, Canada: Concordia University Bookstore, (Reprinted from Harvard Business Review, 76(6), 93-102, 1998).

Guignon, C. B. (1998). Existentialism. In E. Craig (Ed.), Routledge Encyclopedia of Philosophy, 3, 493-502. London, England: Routledge.

Healey, D. (2005). Attention deficit/hyperactivity disorder and creativity: An investigation into their relationship (Unpublished doctoral dissertation). University of Canterbury, Christchurch, New Zealand.

Herculano-Houzel, S., Collins, C. E., Wong, P., Kaas, J. H., \& Lent, R. (2008). The basic nonuniformity of the cerebral cortex. Proceedings of the National Academy of Sciences, 105, 12593-12598. http://dx.doi.org/10.1073/pnas.0805417105

http://www.islamic-council.com (2015). The Egyptian ministry of endowments.

http://www.stooob.com/ 96042.html (2015). Encyclopedia of intellectual and cultural invasion and its effects on Muslims.

Ibn, A., Muhammad, Ibn, A. B., Ibn, A., bin Saad, S., \& Al-Din (1997). The provisions of the dhimmis. The investigator: Yusuf, bin Ahmed, al-Bakri-Shakir, Tawfiq, \& bin Aruri, Dammam: Alramady Publisher.

Ibn, N., Zainuddin, bins Ibrahim, \& bin Mohammed (2010). The minutes of treasure explanation: Creator grant to Ibn Abidin, Dar of Islamic Book.

Ibn, Q., Al-Maqdisi, Abu, M., Muafaqaddin, A., bin Ahmed, \& bin Mohammed (1968). Almughni in the jurisprudence of Imam Ahmad ibn Hanbal al-Shaibani, Cairo: Press Alqahrh.

Ibn, R., Abu, A. W., Muhammad, Ibn, A., \& Alqortobi (1988). The statement, collection and annotation, guidance and explanation of the issues extracted, 2nd Floor. Achieved by: Mohammed Haji et al., Beirut: Dar Muslim West.

Ismail, \& Mohammed, S. (2014). The Malaysian experience Mahathir Mohamad and economic awakening. Cairo: The Arabian for Publication and Distribution, 1, 53.

Khazen, Aladdin, A., bin Mohammed, bin Ibrahim, Al-Baghdadi (1979). The interpretation Khazen called to the door of interpretation in the meanings of the download, Beirut: Dar Alfkir.

Klimoski, R., \& Palmer, S. (1993). The ADA and the hiring process in organizations. Consulting Psychology Journal: Practice and Research, 45(2), 10-36. http://dx.doi.org/10.1037/1061-4087.45.2.10

Kubrick, S. (Director) (1980). The Shining [Motion picture]. United States: Warner Brothers.

Liu, S. (2005). Defending against business crises with the help of intelligent agent based early warning solutions. Paper presented at the Seventh International Conference on Enterprise Information Systems, Miami, FL. Abstract retrieved from http://www.iceis.org/iceis2005/abstracts_2005.htm

MacIntyre, L. (Reporter) (2002). Scandal of the Century [Television series episode]. In H. Cashore (Producer), The fifth estate. Toronto, Canada: Canadian Broadcasting Corporation.

McLuhan, M. (1970a). Culture is our business. New York, NY: McGraw-Hill.

McLuhan, M. (1970b). From cliche to archetype. New York, NY: Viking Press.

Mellers, B. A. (2000). Choice and the relative pleasure of consequences. Psychological Bulletin, 126, 910-924. 
http://dx.doi.org/10.1037/0033-2909.126.6.910

Minority Rights Department. (2011). Shades of the Iraq national richness source. The Republic of Iraq Ministry of Human Rights-performance and protection of rights monitoring circuit.

Postman, N. (1979). Teaching as a conserving activity. New York, NY: Delacorte Press.

Postman, N. (1985). Amusing ourselves to death: Public discourse in the age of show business. New York, NY: Viking.

Sayyid, Q., \& Ibrahim, H. S. (1992). In the shadow of the Koran, Cairo: Dar El Shorouk.

Semenak, S. (1995). Feeling right at home: Government residence eschews traditional rules. Montreal Gazette, A4.

Sherbini, Shams, Al-Din, Muhammad, bin Ahmad, Al-Khatib, \& El-Shafei (1994). Mughna of the needed to know the meanings of the words of the curriculum, Beirut: Dar Scientific Books.

Strong, E. K. Jr., \& Uhrbrock, R. S. (1923). Bibliography on job analysis. In L. Outhwaite (Series Ed.), Personnel Research Series, 1. Job Analysis and the Curriculum, 140-146. http://dx.doi.org/10.1037/10762-000

The Ministry of Endowment and Islamic Affairs-Kuwait. (2006). The Encyclopaedia of Jurisprudence. Kuwait (2nd Floor), Kuwait: Dar salasel.

Zarkashi, Shams, Al-Din, M., bin Abdullah, \& Al-Hanbali (Egyptian) (1993). Explain Zarkashi, Dar Al-Obeikan.

\section{Copyrights}

Copyright for this article is retained by the author(s), with first publication rights granted to the journal.

This is an open-access article distributed under the terms and conditions of the Creative Commons Attribution license (http://creativecommons.org/licenses/by/3.0/). 